\author{
Krzysztof Śpiewla \\ Jagiellonian University in Kraków \\ ORCID: 0000-0002-8955-1444
}

Leszek Świeca

Jagiellonian University in Kraków

ORCID: 0000-0002-2497-3742

\title{
Research on the identification of messages contained in the implicatures of advertisements of over-the-counter products sold in pharmacies in Poland
}

\begin{abstract}
Reports by institutions monitoring this market show that of over PLN 7 billion spent annually in Poland on advertising, almost half is spent on advertising OTC medicines, medical devices and dietary supplements (Instytut Monitorowania Mediów, 2019). Considering this, and taking into account legal regulations that significantly limit promotion at the point of sale (Art. 93 of the Pharmaceutical Law Act), advertising seems to be the most important tool for stimulating demand for over-the-counter products as well as one a basic source of of the residents of Poland on ailments, their treatment and prevention. The study examined 71 advertisements, including 47 ads for medicines, 10 for medical devices, 12 for dietary supplements and 1 ad for food for special medical purposes. Among the sample, 27\% ads contained manipulation in the marketing message. The current tools of market control institutions enable the analysis of explicit claims but not implied messages in advertising. Our analysis shous that this is not enough to protect patients and other market participants from misleading or false advertising. It is absolutely necessary to enhance the control over the advertising of medicines, dietary supplements and medical devices by analysing the implications contained in the advertisements.
\end{abstract}

Keywords: advertising, medicines, dietary supplements, pharmaceutical law, manipulation of medical information

\section{Badania nad identyfikacją przekazu z imlikatur reklam produktów sprzedawanych w aptekach bez recepty w Polsce}

Streszczenie

Analizy instytucji monitorujących ten rynek uykazują, że z ponad 7 miliardów złotych rocznie wydawanych w Polsce na reklamę, blisko połowa przypada na reklamę leków OTC, wyrobów medycznych i suplementów diety. W zuiązku z tym oraz regulacją prawną znacznie ograniczającą 
promocję u miejscu sprzedaży (Art. 93 Ustawy Prawo farmaceutyczne) reklama produktów farmaceutycznych wydaje się najważniejszym instrumentem pobudzania popytu na produkty dostępne w aptekach bez recepty oraz podstawowym źródłem wiedzy mieszkańców Polski na temat dolegliwości i ich leczenia oraz profilaktyki. Badaniu poddano 71 badanych reklam: $47 \mathrm{z}$ nich to reklamy leków, 10 - wyrobów medycznych, 12 - suplementów diety i 1 żywności specjalnego przeznaczenia medycznego, aż u 27\% stuierdzono manipulację przekazem marketingouym. Obecne narzędzia instytucji kontroli rynku umożliwiają analizę treści eksplikowanych, ale nie implikowanych przez reklamę. Przeprowadzona analiza wykazuje, że nie wystarcza to, aby zabezpieczyć pacjentów i innych uczestników rynku przed nieuczciwą reklamą. Bezwzględnie konieczne jest uzupełnienie nadzoru nad reklamami leków, suplementów diety oraz uyrobów medycznych o analizę imlikatur zawartych w reklamach.

Słowa kluczowe: reklama, leki, suplementy diety, prawo farmaceutyczne, manipulacja informacją medyczną.

\section{Introduction}

The market for over-the-counter products is one of the largest sources of advertising revenue in Poland. Reports by institutions monitoring this market show that of over PLN 7 billion spent annually in Poland on advertising, almost half is spent on advertising OTC medicines, medical devices and dietary supplements ${ }^{1}$. Considering this, and taking into account legal regulations that significantly limit promotion at the point of sale (Art. 93 of the Pharmaceutical Law Act ${ }^{2}$ ), advertising seems to be the most important tool for stimulating demand for over-the-counter products ${ }^{3}$, as well as one of the basic sources of knowledge on ailments, their treatment and prevention for the residents of Poland.

Despite the existence of relevant legal regulations and institutions overseeing the honesty of advertising of pharmaceutical products, advertisers use techniques that allow them to bypass those controls and even to manipulate the recipient. A case study of only one product category, consisting of only two products, identified the following problems with the honesty of pharmaceutical advertising 4 .

- Claims that the product, which doesn't have a status of a "medicinal product" or relevant clinical trials, can be used to treat (cure) an ailment or a condition,

\footnotetext{
${ }^{1}$ Institute of Media Monitoring, The pharmaceutical industry has invested the most. IMM report: Advertising expenditure in selected industries in January 2019, https://wwu.imm.com.pl/ branza-farmaceutyczna-wydala-najwiecej-na-reklame-raport-imm-wydatki-reklamowe-w-wybranych-branzach-w-styczniu-2019/ (accessed on: 2.04.2019).

2 Act of September 62001 - Pharmaceutical Law, Journal of Laws of 126, item. 1381 (accessed on: 2.04.2019).

${ }^{3}$ M. Zarzeczna-Baran et al., Wptyw reklamy na zakup leków dostęnych bez recepty. "Ann. Med. Acad. Gedan." 2013, no. 43, p. 77-87.

${ }^{4}$ K. Śpiewla, L. Świeca, Selected aspects of risks related to advertising drugs and medical devices - case study, „Scientific and methodical review of education for security” 2018, no. 3(40), p. 343-354.
} 
- suggesting or claiming a broader spectrum of application than the product actually has,

- using the professional authority of a doctor (in the case of medical device advertising),

- suggesting other (broader) indications for a medicinal product than specified in the product documentation.

The aforementioned effects are a result of both rematizazation of messages, as well as rhetorical (framing) or execution processes difficult to assess for the average recipient. Due to the significance of the issue, we have analysed the content of a larger number of advertisements.

The aim of the study is to investigate how often the aforementioned issues occur, possibly discover more of them and determine whether the legal classification (medicinal product - medical product - dietary supplement) impacts the choice of manipulation tactics used by advertisers.

\section{Methodological aspects of research}

The analysis concerned 308 different television commercials broadcast in Poland in February 2019. These were arbitrarily grouped into market categories, according to usage indications. Adverts for the following types of products were excluded from the analysis:

- cosmetics, vitamin and mineral supplements, other beauty supplements,

- products belonging to categories in which only one brand exists,

- short versions of longer advertisements and sponsor billboards.

The analysis covered 71 ads belonging to 11 categories.

Table 1. Analysed advertisements by product category.

\begin{tabular}{|l|c|}
\hline \multicolumn{1}{|c|}{ Product categories } & Number of ads \\
\hline Anti-diarrhoea products & 3 \\
\hline Sore throat and hoarse voice remedies & 8 \\
\hline Irritable bouel syndrome products & 2 \\
\hline Female "intimate" infections products & 2 \\
\hline Cough remedies & 17 \\
\hline Nasal drops and sprays & 8 \\
\hline Sleep aids & 3 \\
\hline Prebiotics and synbiotics & 6 \\
\hline Joint pain and musculoskeletal injury products & 11 \\
\hline Sedatives & 5 \\
\hline Liver complaints products & 2 \\
\hline Constipation remedies & 4 \\
\hline Total & 71 \\
\hline
\end{tabular}

Source: own research. 
Among the examined commercials, 47 advertised medicines; 10 advertised medical devices, 12, dietary supplements; and 1, food for special medical purposes.

The standard content analysis method was used. Following the findings of a previous study ${ }^{5}$, the analysis aimed to identify the following manipulation techniques:

1. Additional treatment indications beyond the indications specified in the product documentation (especially in the patient leaflets or the summary of product characteristics in the case of medicines);

2. claiming that the product can cure (treat) an ailment or condition, even though it is not a medicine (medicinal product). As a medical device can be used for treatment only when "it does not achieve the intended action in the body or on the human body by pharmacological, immunological or metabolic means, but whose action can be supported by such means" (Art. 2 of the Act of 20 May 2010 on medical devices), for this class of products, the analysis most often required verification of information about clinical trials cited by advertisers.

3. Explicit claims of benefits not matching the documentation or scientific information on the product or its components;

4. Implicit suggestions of benefits not matching the documentation or scientific information on the product or its components.

Implication techniques include linguistic means that allow for saying more than the explicit content of the text as-written thanks to ambiguity ${ }^{6}$; adopting a particular register (e.g. scientific and medical); scientific terminology; using structures, established in language, which confirm the truthfulness of statements; as well as misusing large quantifiers and adjective and adverb grades ${ }^{7}$. When analysing the use of manipulation techniques in implicatures of advertising material, it should not be forgotten that advertising draws from a broader media and cultural context and incorporates such borrowed meanings into its persuasive message ${ }^{8}$. Such use of culture by advertising is also called discourse exploitation ${ }^{9}$. Finally, the conceptual framework, both invoked by senders of given advertisements and resulting from the general convention of pharmaceutical advertising, is significant. Framing, i.e. invoking such a framework, influences the interpretation of the message by its recipients, including reducing their critical attitude.

\footnotetext{
${ }^{5}$ Ibidem, p. 343-354.

${ }^{6}$ P.H. Lewiński, Retoryka reklamy, Wydawnictuo Uniwersytetu Wrocłauskiego, Wrocław 1999, p. 193-194.

7 J. Bralczyk, Język na sprzedaż, Branta, Warszawa 2000, p. 28-43.

${ }^{8}$ M. Lisouska-Magdziarz, Analiza tekstu $w$ dyskursie medialnym, Wydawnictuo Uniwersytetu Jagiellońskiego, Kraków 2006, p. 64-78.

9 F.L. Johnson, Imaging in advertising: Verbal and visual codes of commerce, Routledge, New York 2012, p. 9-12.
} 


\section{Results}

\section{Treatment indications beyond those specified in the product documentation}

The vast majority (69) of the analysed commercials (97\% of the total), including one advertisement for a homeopathic medicine, did not contain such inaccuracies. The two cases in which it occurred included:

Informing patients that the product treats intimate infections in general, while it is intended for the treatment of fungal infections. The information narrowing the indications is displayed on the screen in small print for 6 seconds, but at the same time, other, highlighted text, animated product packaging, and an actress, are also shown, while 16 words are spoken in the audio layer. It is difficult to consider this information as perceptible to a typical recipient.

The character in the commercial for a medicine that reduces "subjective complaints such as lack of appetite, tightness in the right epigastric region caused by liver damage as a result of improper diet, toxic substances or hepatitis" (patient leaflet for Essentiale $\operatorname{Max}^{10}$ ) intends to eat a hamburger. The voice-over admonishes him for the sake of his liver. The character says: "Relax, I have Essentiale Max", followed by the presentation of the product. This is a clear, albeit implicit, indication for using the product as a protection against the effects of a hard-to-digest diet. This indication is not included in the product leaflet, moreover, the leaflet contains a clear warning against using the product for this purpose: "the use of Essentiale Max cannot replace excluding harmful substances that cause liver damage from the diet" (Essentiale Max patient leaflet).

\section{Claiming that the product is can cure (treat), even though it is not a medicine (medicinal product)}

After a thorough analysis of the indications in medical device advertisements, manipulation attempts in this regard were detected in four cases, i.e. 7\% of all analysed advertisements. Three of these cases concern advertisements for medical devices, making up a substantial $30 \%$ of analysed ads in this product category. One questionable dietary supplement ad accounts for $8 \%$ of analysed advertisements in this product category.

One case involves a classic misuse of a large quantifier - the product is advertised as a remedy for "all throat matters" (this is a play on words with a Polish idiom of "throat matters" meaning urgent and important matters). Talking about "all" such matters implies also those that would require treatment with medicinal products or medical devices (the advertised product is a dietary supplement). The advertiser may feel safe from the legal point of view, because the idiom "throat matters" used in the commercial

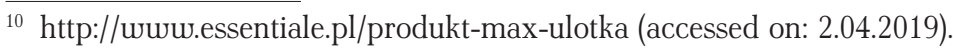


does not concern a sore throat, but a crisis situation. It can therefore be said that its use in this context is purely abstract.

The next two ads suggest that the product is curative while in fact it can only alleviate symptoms. The most important manipulation here is the use of the word 'for', which automatically refers the recipient to the semantic framework of medicines discourse, by using a simple linguistic stereotype that simultaneously simplifies the message and adds an interpretative surplus ${ }^{11}$. Interestingly, both commercials using this manipulation technique advertise very similar products, medical devices in the form of syrups "for" any type of cough.

Another commercial, advertising a medical device for women's intimate infections, analysed previously ${ }^{12}$ provides a clear indication that the product is curative. In the commercial aired at the time of writing this article, a doctor says "You need to start treatment" and recommends the advertised medical device to the patient, which, according to the product documentation, is suitable for adjunctive rather than primary treatment.

\section{Explicit claims of benefits not matching the documentation or scientific information on the product or its components}

Two such instances were identified, both in ads for medical devices (3\% of the total and $20 \%$ of advertisements for medical devices).

The first case involves a claim of efficacy with undisclosed evidence: the commercial refers to a study, but the study has not been published. In this situation, neither the consumer, nor public bodies and NGOs dealing with consumer protection are able to verify the information provided in the advertisement.

The second advertisement uses a whole range of manipulation techniques. The first problem is similar to the case described above, i.e. claiming efficacy of the product without a published source of such information. Secondly, the product is named after a medicine, and the component 'Xylo-' suggests xylometazoline, a commonly used active ingredient in this product category. This, again, invokes a linguistic stereotype. Finally, the advertisement states that using the product will definitely result in unblocked nose, while according to the manufacturer's information ${ }^{13}$, the product only helps to unblock the nose.

\section{Implicit suggestions of benefits incompatible with the documentation or scientific information on the product or its components}

As many as 17 out of the 71 examined advertisements (i.e. 24\%), used manipulation techniques in this respect. The misleading commercials included:

- 8 ads for medicines (medicinal products) (17\%),

${ }_{11}$ M. Lisouska-Magdziarz, op. cit., p. 91.

12 K. Śpieula, L. Świeca, op. cit., p. 343-354.

${ }^{13}$ wuw.xylorin.pl (accessed on: 2.04.2019). 
- 5 ads for medical devices (50\%),

- 4 ads for dietary supplements (33\%).

Among the advertisements for medicines, the commercials discussed in previous sections were again identified, with implicatures used to communicate non-existing indications.

A commercial for another medicine creates a misleading impression of the composition of the product as compared to the competition. A clear, highly rhematized message concerns a "twice as high" dose of the active substance. A small, poorly legible print displayed on the screen explains that comparison only concerns products containing half the amount of the active substance. This explanation is, however, written in a way that is difficult to understand, containing fractions and measures, and thus requires a lot of effort from the recipient, effort impossible during ordinary viewing of an advertisement. The double-dose message implies the assumption that all other products in the category, not just those products selected for comparison, contain half the dose. In this case, framing was used ${ }^{14}$, while an always-true statement ${ }^{15}$ provided protection against potential accusations of misleading claims. Due to the existence of products on the market with the same dose as the advertised, the impression created by the ad on the recipient is false.

In another advertisement, the visual message is in conflict with the medicine's documentation. The product is intended for children over 2 years old, and can be used for children aged 2 to 4 only after a doctor's consultation ${ }^{16}$. However, in the last shot of the commercial, a mother, holding and open bottle of the product, leans over a baby and touches her in a gesture suggesting that she intends to give the medicine to the baby, who is apparently younger than 2 years. It is a narrative and kinesic movement, with a goal of showing what to do with the product, supplementing the verbal communication and making it more precise ${ }^{17}$. Although the woman's gestures do not conclude in giving the medicine to the baby (the scene is interrupted by the end of the advertisement), however, based on the cultural context, which consist in a certain degree of familiarity with video/cinema, and especially commercials, the recipient can easily construct the continuation of the situation shown.

Pharmaceutical advertising often utilizes a manipulative technique consisting in an ambiguous text that can be read in a variety of ways, including in a manner that is in the advertiser's interest, but not permitted by the law, because it misleads the recipient. In case of legal and ethical doubts, such text may be interpreted in favour of the advertiser. An example is the aforementioned solution "for every throat matter", but also the slogan that has been used for years "Stronger medicine than pain" [Pol. Silniejszy lek od bólu, literally translated: Stronger medicine than pain, where the Polish

\footnotetext{
${ }_{14}$ M. Lisouska-Magdziarz, op. cit., p. 77-78.

15 J. Bralczyk, op. cit., p. 35.

${ }^{16}$ Package leaflet: information for the patient. Hederasal (accessed on: 2.04.2019).

${ }_{17}$ M. Makouski, Niewerbalna komunikacja $w$ reklamie telewizyjnej-Zastosowanie i oddziatywanie, CeDeWu, Warszawa 2013, p. 228-231.
} 
preposition "od" denotes both "for" (i.e. indicated-for) and "than"]. The slogan can be understood as meaning that the product has the strength to overcome, i.e. relieve pain (it is stronger than pain), but, thanks to the Polish syntax, also that it is stronger than other "medicines for pain", according to the commonly used in colloquial Polish construction „lek od...." (medicine, product, powder, ointment) for...", which specifies indications for use. analysed material also contained an advertisement using this slogan in the version "Stronger medicine [than/for] pain in the back, muscles, joints".

The next ad in this category of manipulation presents a benefit that the product does not necessarily provide at all. The advertiser rhematizes the benefit of DMSO content - "an ancillary substance that increases the rate of absorption" of the active substance. At the same time, in small print, the ad informs that this benefit is not proven at all, but only that "it cannot be ruled out that the absorption of naproxen after the use of the medicinal product will be greater than after the use of other medicines containing the same concentration and pharmaceutical form of naproxen, but not containing DMSO in their composition." The text, in small print, appears on the screen for 3 seconds, while at the same time one of the actors utters 10 words in the audio layer. In this case, it is also difficult to assume that the recipient in a normal situation of receiving the ad will be able to perceive the displayed text. In this case, the advertiser protects himself from legal liability by using a statement whose "indisputability does not come from absolute and obvious truthfulness, but from the impossibility to state that it is not so"18, while at the same time presenting a certain kind of argumentum ad verecundiam to the recipient, introducing a scientific style of expression that inspires confidence $^{19}$.

Another widely used manipulation technique is to highlight certain features or benefits, suggesting that they are unique to the product being advertised, while they are typical for several competitors. For example, the advertiser of one of the topically acting medicines containing diclofenac as the active substance states that his product "works 3 times faster and is 10 times more concentrated in the location of the pain" and quotes a scientific publication ${ }^{20}$. However, the cited publication ${ }^{21}$ concerns all topically applied products with diclofenac and compares their advantages with products administered systemically. At the same time, as a rule, product advertising highlights the product's advantages against others in the same category. This results not only from the definition of "product category"22 but above all from the context of communication: the communication situation and the broad and narrow media contex $\mathrm{t}^{23}$. In this case,

\footnotetext{
18 J. Bralczyk, op. cit., p. 36.

19 Ibidem, p. 31-32.

${ }^{20}$ wuw.traumon.pl/badania (accessed on: 2.04.2019).

${ }^{21}$ F. Rannou, J.P. Pelletier, J. Martel-Pelletier, Efficacy and safety of topical NSAIDs in the management of osteoarthritis: Evidence from real-life setting trials and surveys, "Seminars in Arthritis and Rheumatism" 2016, no. 45, p. 18-21.

${ }^{22}$ A. Kobyłt, Kategoria produktów w jednostkach handlowych, "Logistyka i Transport" 2006, vol. 2, p. 27-33.

${ }^{23}$ M. Lisouska-Magdziarz, op. cit., p. 64-67.
} 
the method of interpretation (and thus the choice between products) is very narrouly defined by the context, i.e. the reception of advertising, and the delineated product category - local remedies for musculoskeletal pain. Therefore, one can risk the statement that the analysed message misleads the recipient. Another example concerns a product praised in its advertisement for being sugar and alcohol free and non-addictive, which are typical features for products in this category.

The advertisements for medical devices that imply features or benefits other than those that can be explicitly stated include the 4 advertisements suggesting curative applications, discussed above.

Moreover, one of the advertisements claims that it is the only medical device for hoarse voice containing two ingredients available. And this is true, but the category [of remedies for hoarseness] is also made up of products in other classes, including dietary supplements with composition similar to the composition of the advertised product. It is well known that patients in Poland do not distinguish between classes of OTC products and treat OTC medicines, medical devices and dietary supplements with equal confidence, and often are not even aware of the existence of these classes ${ }^{24}$. Therefore, the situation is the same as for a DMSO-containing product, discussed above - artificial narrowing of the category to make the product unique.

A massage therapist appears in the advertisement for dietary supplement supporting healthy joints. He shows how mobile his wrists are and indicates that this is the effect of using the product. The advertisement continues to claim that the product's ingredients rebuild degenerated articular cartilage in 12 weeks. This is a curative effect, and the authors of the advertisement cite the relevant study ${ }^{25}$ as evidence. The study shows, however, that the use of a product with a composition corresponding to the advertised supports rehabilitation in osteoarthritis, and not that it replaces it. However, the advertisement makes the impression that just taking the advertised supplement allows for a gradual recovery. Here again, the scientific tone and the authority of a professional were used to reduce critical reception. A critical recipient would notice that a massage therapist would be expected to have high urists mobility, because he uses his wrists at work every day - the mobility is certainly the effect of keeping the joints mobile, and not necessarily of taking the dietary supplement.

Another dietary supplement in this category uses the technique already discussed above for medicines - it advertises the product features typical of the category as the product's unique advantages. In this case, it's the ingredients.

Another advertisement for a dietary supplement that merits critical attention, communicates a side effect as a primary benefit, and also reinforces the belief that the product helps in weight loss. The product is primarily aiming to support the liver [function],

${ }^{24}$ K. Rybus, M. Kozłouska-Wojciechouska, The use of dietary supplements and overthe-counter (OTC) medicines by the elderly-survey results, "Czynniki Ryzyka" 2010, no. 1, p. 32-37. ${ }^{25}$ K. Sengupta, e. a., Comparative Efficacy and Tolerability of 5-Loxin ${ }^{\circledR}$ and Aflapin ${ }^{\circledR}$ Against Osteoarthritis of the Knee: A Double Blind, Randomized, Placebo Controlled Clinical Study. "International Journal of Medical Sciences" 2010, no. 7(6), p. 366-377. 
but also to control body weight. However, the characters in the commercial refer to it as a "weight loss" product. According to health claims, this product's ingredients can only help maintain normal weight by improving digestion (EU Register on nutrition and health claims). It is worth adding that there are currently no dietary supplements with proven slimming effect on the Polish market (Wierzejska). The conversation between the characters introduces a conceptual framework within which weight loss supplements exist and women commonly use them.

Finally, it is worth mentioning the practice of dietary supplement manufacturers, in which the curative effects of the products are not claimed explicitly, but implicitly suggested. One such case was observed in the examined material. A dietary supplement (which according to the definition should support the proper functioning of the body in a given area) is described in the advertisement as "sedative tablets" and its action is defined as "soothing nerves". Sedation and nerves-soothing should be considered pharmacological effects, and hence, the product - if it actually does have such effects should be registered as a medicine.

Manipulation techniques were used in 19 out of 71 examined advertisements, i.e. in $27 \%$ of them. The following tables summarizes types of manipulation by product class:

Table 2. Types of manipulation by product class

\begin{tabular}{|c|c|c|c|c|c|c|c|c|c|}
\hline Product class & $\begin{array}{c}\text { Number } \\
\text { of ads } \\
\text { analysed }\end{array}$ & $\begin{array}{r}\text { Indi } \\
\text { beyor } \\
\text { in docu }\end{array}$ & $\begin{array}{l}\text { ons } \\
\text { hose } \\
\text { ntation }\end{array}$ & $\begin{array}{r}\mathrm{Cl} \\
\text { as cur } \\
\text { thol } \\
\text { a m }\end{array}$ & $\begin{array}{l}\text { ed } \\
\text { e even } \\
\text { not } \\
\text { cine }\end{array}$ & $\begin{array}{l}\text { Unj } \\
\text { exp } \\
\text { of fe } \\
\text { be }\end{array}$ & $\begin{array}{l}\text { ied } \\
\text { ion } \\
\text { es / } \\
\text { ts }\end{array}$ & $\begin{array}{r}\text { Unj } \\
\text { impl } \\
\text { of fe } \\
\text { be }\end{array}$ & $\begin{array}{l}\text { ied } \\
\text { ions } \\
\text { es / } \\
\text { ts }\end{array}$ \\
\hline $\begin{array}{l}\text { Food for special } \\
\text { medical purposes }\end{array}$ & 1 & n. d. & n. d. & 0 & $0 \%$ & 0 & $0 \%$ & 0 & $0 \%$ \\
\hline Medicine & 48 & 2 & $4 \%$ & n. d. & n. d. & 0 & $0 \%$ & 8 & $17 \%$ \\
\hline A dietary supplement & 12 & n. d. & n. d. & 1 & $8 \%$ & 0 & $0 \%$ & 4 & $33 \%$ \\
\hline Medical device & 10 & n. d. & n. d. & 3 & $30 \%$ & 2 & $20 \%$ & 5 & $50 \%$ \\
\hline Total & 71 & & & & & 2 & $3 \%$ & 17 & $24 \%$ \\
\hline
\end{tabular}

Source: own research.

Table 3. Types of manipulation by product category

\begin{tabular}{|l|c|c|c|c|c|c|c|c|c|}
\hline \multicolumn{1}{|c|}{ Product category } & $\begin{array}{c}\text { Number } \\
\text { of ads } \\
\text { analysed }\end{array}$ & \multicolumn{2}{|c|}{$\begin{array}{c}\text { Indications } \\
\text { beyond those } \\
\text { in documentation }\end{array}$} & \multicolumn{2}{c|}{$\begin{array}{c}\text { Claimed } \\
\text { as curative even } \\
\text { though not } \\
\text { a medicine }\end{array}$} & \multicolumn{2}{|c|}{$\begin{array}{c}\text { Unjustified } \\
\text { explication } \\
\text { of features / } \\
\text { benefits }\end{array}$} & \multicolumn{2}{c|}{$\begin{array}{c}\text { Unjustified } \\
\text { implications } \\
\text { of features / } \\
\text { benefits }\end{array}$} \\
\hline Diarrhoea & 3 & 0 & $0 \%$ & 0 & $0 \%$ & 0 & $0 \%$ & 0 & $0 \%$ \\
\hline Throat & 8 & 0 & $0 \%$ & 1 & $13 \%$ & 1 & $13 \%$ & 1 & $13 \%$ \\
\hline IBS & 2 & 0 & $0 \%$ & 0 & $0 \%$ & 0 & $0 \%$ & 0 & $0 \%$ \\
\hline intimate infections & 2 & 1 & $50 \%$ & 1 & $50 \%$ & 0 & $0 \%$ & 2 & $100 \%$ \\
\hline Cough & 17 & 0 & $0 \%$ & 2 & $12 \%$ & 0 & $0 \%$ & 5 & $29 \%$ \\
\hline $\begin{array}{l}\text { nasal drops } \\
\text { and sprays }\end{array}$ & 8 & 0 & $0 \%$ & 0 & $0 \%$ & 2 & $25 \%$ & 1 & $13 \%$ \\
\hline sleep aid & 3 & 0 & $0 \%$ & 0 & $0 \%$ & 0 & $0 \%$ & 0 & $0 \%$ \\
\hline
\end{tabular}


Research on the identification of messages...

\begin{tabular}{|l|c|c|c|c|c|c|c|c|c|}
\hline \multicolumn{1}{|c|}{ Product category } & $\begin{array}{c}\text { Number } \\
\text { of ads } \\
\text { analysed }\end{array}$ & \multicolumn{2}{|c|}{$\begin{array}{c}\text { Indications } \\
\text { beyond those } \\
\text { in documentation }\end{array}$} & \multicolumn{2}{c|}{$\begin{array}{c}\text { Claimed } \\
\text { as curative even } \\
\text { though not } \\
\text { a medicine }\end{array}$} & \multicolumn{2}{|c|}{$\begin{array}{c}\text { Unjustified } \\
\text { explication } \\
\text { of features / } \\
\text { benefits }\end{array}$} & \multicolumn{2}{c|}{$\begin{array}{c}\text { Unjustified } \\
\text { implications } \\
\text { of features / } \\
\text { benefits }\end{array}$} \\
\hline general probiotics & 6 & 0 & $0 \%$ & 0 & $0 \%$ & 0 & $0 \%$ & 0 & $0 \%$ \\
\hline $\begin{array}{l}\text { musculoskeletal } \\
\text { injuries }\end{array}$ & 11 & 0 & $0 \%$ & 0 & $0 \%$ & 0 & $0 \%$ & 5 & $45 \%$ \\
\hline Sedatives & 5 & 0 & $0 \%$ & 0 & $0 \%$ & 0 & $0 \%$ & 1 & $20 \%$ \\
\hline liver & 2 & 1 & $50 \%$ & 0 & $0 \%$ & 0 & $0 \%$ & 2 & $100 \%$ \\
\hline constipation & 4 & 0 & $0 \%$ & 0 & $0 \%$ & 0 & $0 \%$ & 0 & $0 \%$ \\
\hline Total & 71 & 2 & $3 \%$ & 3 & $4 \%$ & 3 & $4 \%$ & 17 & $23.94 \%$ \\
\hline
\end{tabular}

Source: own research.

The most common are techniques that use implicatures. This is understandable as literal manipulation is easy to detect and prove by consumers themselves or by market control institutions. Only three ads explicitly state important information that is false or easily undermined, while 17 out of 19 questionable commercials contain such messages implicitly.

As can be seen in the tables presented above, questionable practices often occur in the advertising of medical devices. As for the categories of products in which they are common, remedies for pain and injuries to the musculoskeletal system stand out in the examined material, with nearly half of advertisements in this category questionable.

Closer quantitative analysis of the use of manipulative implicatures looks as follows:

- Ambiguous text - 5 ads

- Situational (resulting from the plot, characters' actions, or staging of the commercial) suggestions of indications or use of the product -3 ads

- Artificial narrowing of the field of comparison with competitors - 3 ads

- Presentation of features typical of many products as unique to the advertised - 3 ads

- Situational (resulting from the staging of the commercial) suggesting non-existent benefits -2 ads

- Too general an indication ("intimate infections" instead of "intimate fungal infections") -1 ad

- Use of the word 'cure', 'treat', 'treatment' when referring a medical device - 1 ad

- Using a "red herring" - a scientific study that in fact does not talk about the benefits of using the preparation - 1 ad.

\section{Summary}

The conducted study shous that the rhetorical techniques most frequently used for manipulation are those which incorporate implicature. These are ambiguities, the use of staging measures, modulating the meaning of verbal utterances and the entire message, as well as fallacies, which are unidentifiable for the intended recipient. Advertisers 
avoid verbal manipulation due to the ease of its detection. Attempts of manipulation can be most often found in advertisements of medicinal products, less frequently - dietary supplements and drugs. The category of products whose advertising can most often be considered unreliable are products related to locomotor system pain.

The practical conclusion drawn from the study is that advertisers do not feel threatened by sanctions from state market control institutions in the event of using manipulative implicatures, while simultaneously are wary of explicit manipulation in the verbal layer of messaging. This may arise from the fact that control institutions lack the competence and willingness to evaluate the manipulative nature of implicatures in advertising messaging. It is recommended to continue interdisciplinary studies in the area of recipient disinformation in the advertising of drugs, medicinal products and dietary supplements, in order to protect the health and life of advertising audiences.

\section{References}

Bralczyk J., Język na sprzedaż, Branta, Warszawa 2000.

Hys K., Wpływ przekazu handlowego na sprzedaż produktów leczniczych i suplementów diety $w$ Polsce, "Zarządzanie. Teoria i Praktyka" 2017, no. 4 (22).

Johnson F.L., Imaging in advertising: Verbal and visual codes of commerce, Routledge, New York 2012.

Kobyłt A., Kategoria produktów w jednostkach handlowych, "Logistyka i Transport" 2006, vol. 2.

Lewiński P.H., Retoryka reklamy, Wydaunictwo Uniwersytetu Wrocłauskiego, Wrocław 1999.

Lisouska-Magdziarz M., Analiza tekstu $w$ dyskursie medialnym, Wydawnictwo Uniwersytetu Jagiellońskiego, Kraków 2006.

Makouski M., Niewerbalna komunikacja $w$ reklamie telewizyjnej-Zastosowanie i oddziatywanie, CeDeWu, Warszawa 2013.

Rannou F., Pelletier J.P., Martel-Pelletier J., Efficacy and safety of topical NSAIDs in the management of osteoarthritis: Evidence from real-life setting trials and surveys, "Seminars in Arthritis and Rheumatism" 2016, no. 45.

Rybus K., Kozłouska-Wojciechouska M., The use of dietary supplements and overthe-counter (OTC) medicines by the elderly - survey results, "Czynniki Ryzyka" 2010, no. 1.

Sengupta K. e. a., Comparative Efficacy and Tolerability of 5-Loxin ${ }^{\circledR}$ and Aflapin ${ }^{\circledR}$ Against Osteoarthritis of the Knee: A Double Blind, Randomized, Placebo Controlled Clinical Study, "International Journal of Medical Sciences" 2010, no. 7(6).

Śpiewla K., Świeca L., Selected aspects of risks related to advertising drugs and medical devices - case study, "Scientific and Methodical Review of Education for Security" 2018, no. 3(40).

Wierzejska R., Suplementy diety-panaceum na wspótczesne dolegliwości zdrowotne czy triumf reklamy?, "Medycyna Rodzinna" 2017, no. 20(2).

Zarzeczna-Baran M. et al., Wpływ reklamy na zakup leków dostępnych bez recepty, "Annales Academiae Medicae Gedanensis" 2013, no. 43. 


\section{Legislation}

Act of September 62001 - Pharmaceutical Law, Journal of Laws of 126, item. 1381 (accessed on: 4.03.2019).

Act of 20 May 2010 on medical devices, Journal of Laws 2010 no. 107 item 679 (accessed on: 4.03.2019).

\section{Internet}

Essentiale Max patient leaflet, http://www.essentiale.pl/produkt-max-ulotka (accessed on: 2.04.2019). EU register on nutrition and health claims. http://ec.europa.eu/food/safety/ labelling_nutrition/claims/register/public/?event=search (accessed on: 3.04.2019).

https://pub.rejestrymedyczne.csioz.gov.pl/Pobieranie.ashx?type=10121-u (accessed on: 2.04.2019). Institute of Media Monitoring, The pharmaceutical industry has invested the most. IMM report: Advertising expenditure in selected industries in January 2019, https://www.imm.com.pl/ branza-farmaceutyczna-wydala-najwiecej-na-reklame-raport-imm-wydatki-reklamowe-wwybranych-branzach-w-styczniu-2019 (accessed on: 2.05.2019).

Package leaflet: patient information Hederasal (accessed on: 2.04.2019).

wuw.traumon.pl/badania (accessed on: 2.04.2019).

wuw.xylorin.pl (accessed on: 2.04.2019).

Zenith, after: Polish advertising this year 2.3 percent up. The Internet will gain $8 \%$, the press will lose 12\% (analysis), https://www.wirtualnemedia.pl/artykul/uydatki-reklamowe-w-2018-roku (accessed on: 4.03.2019). 